\title{
O CRU, O COZIDO E O POLICIAL: entrevista a Rodolfo Pérez Valero
}

THE RAW, THE COOKED AND THE CRIMINAL: interVieW With Rodolfo Pérez Valero

\section{Emilio J. Gallardo-Saborido}

Universidade de Sevilha

Sevilha, Espanha

\begin{abstract}
Resumo
A figura de Rodolfo Pérez Valero (Guanabacoa, Cuba, 1947) é fundamental para conhecer o desenvolvimento da literatura policial cubana, dada sua extensa e destacada dedicação ao gênero como criador, mas também por sua faceta de agitador e gestor cultural. Nesta entrevista, Pérez Valero reflete, entre outras questóes, sobre as relaçóes entre o poder político cultural e a literatura policial na Cuba das décadas de 1970 e 1980.
\end{abstract}

Palavras-chave: literatura cubana, literatura policial, Rodolfo Pérez Valero, Quinquênio Cinza.

\section{Abstract}

The writer Rodolfo Pérez Valero (Guanabacoa, Cuba, 1947) is crucial to understand the development of the Cuban crime fiction because of his vast and outstanding devotion to this genre as creator, and because of his work as cultural agitator and manager. In this interview, Pérez Valero reflects on, among other issues, the relationships between cultural politics and crime fiction in Cuba in the decades of 1970 and 1980.

Keywords: Cuban literature, crime fiction, Rodolfo Pérez Valero, Quinquenio Gris.

\section{Resumen}

La figura de Rodolfo Pérez Valero (Guanabacoa, Cuba, 1947) es fundamental para conocer el desarrollo de la literatura policial cubana, dada su extensa y destacada dedicación al género como creador, pero también por su labor como agitador y gestor cultural. En esta entrevista, Pérez Valero reflexiona, entre otras cuestiones, sobre las relaciones entre el poder político cultural y la literatura policial en la Cuba de las décadas de 1970 y 1980 .

Palabras claves: literatura cubana, literatura policial, Rodolfo Pérez Valero, Quinquenio Gris. 
Nascido em Guanabacoa, (Cuba), em 1947, Rodolfo Pérez Valero se destacou, entre outras conquistas, por obter em até cinco ocasiōes o primeiro prêmio de contos da Semana Negra de Gijón. Seu romance No es tiempo de ceremonias (1974) é considerado uma das peças-chave da narrativa policial da Revolução. Em 1986, fundou em Havana, junto com outros autores, a Associação Internacional de Escritores Policiais (AIEP). Seu órgão de difusão foi a revista Enigma (1986-1989), dirigida pelo próprio Pérez Valero e pelo também escritor Alberto Molina.

Entre seus últimos livros está uma coletânea de contos policiais intitulada Un hombre toca a la puerta bajo la lluvia, editada no México em 2010 pela Plaza \& Janés; o romance Habana-Madrid, lançado em 2012 com a chancela da Plaza; os romances juvenis Misterio en el Caribe (Plaza, 2015), Misterio en Venecia (Plaza, 2006) e Misterio en Nueva York (Plaza, 2017).

A figura de Pérez Valero é fundamental para conhecer o desenvolvimento da literatura policial cubana, dada sua extensa e destacada dedicação ao gênero como criador, mas também por sua faceta de agitador e gestor cultural. Nesta entrevista, Pérez Valero reflete, entre outras questóes, sobre as relaçóes entre o poder político cultural e a literatura policial na Cuba das décadas de 1970 e 1980.

Entrevistador (E): Se estiver de acordo, podemos começar falando sobre o seu período de formaçáo na Escola Nacional de Arte de Cuba e na Universidade de Havana.

Rodolfo Pérez Valero (RPV): Meu primeiro encontro com a formação artística aconteceu em 1966, ano em que ingressei na Escola de Arte. Antes disso, estudei nos Escolapios de Guanabacoa até os doze anos, momento em que a Revolução triunfou. Naquela ocasião, pensávamos em sair do país, razão pela qual deixei de estudar e comecei a trabalhar. Em 1966, meus pais foram para os Estados Unidos e, por causa de uma lei criada pelo governo para evitar o êxodo das famílias, não pude acompanhá-los, já que os jovens em idade de cumprir o serviço militar tinham sido proibidos de sair do país. Sabia-se que, nos colégios internos, também davam instrução militar, tornando possível que o aluno náo tivesse que fazer o serviço militar. Isto me levou a tentar entrar em um colégio daqueles. Naquela época, ouvia e conhecia muitas cançôes, e vi uma chamada da Escola Nacional de Arte para musicalizador e pensei que seria agradável trabalhar podendo utilizar esse conhecimento. Então, para evitar o serviço militar e com essa única ideia cultural, entrei na Escola de Arte. Já tinha escrito alguns poemas. Achava, de fato, que todos os jovens escreviam poemas. 
A Escola Nacional de Arte, a ENA, teve sobre mim um tremendo impacto positivo. Quando cheguei lá, senti que todos os outros que, como eu, estudavam na escola de arte dramática sabiam muitíssimo, por terem trabalhado antes como amadores em peças teatrais, e eu não. $\mathrm{O}$ primeiro passo importante que me fortaleceu como criador foi a iniciativa de $E l$ Caimán Barbudo de fazer, creio que em 1967, uma edição dedicada aos jovens escritores da Escola de Arte. E me atrevi a entregar um poema, junto com outros alunos conhecidos por escrever e que todos considerávamos intelectuais. Finalmente meu poema foi selecionado, e o fato de vê-lo publicado no $E l$ Caimán Barbudo, um jornal extremamente importante para a juventude, produziu um impulso, como se eu tivesse escrito um romance.

A partir desse momento comecei a escrever contos e creio que isso ocorreu porque realmente eu não entendia a poesia. Buscava livros que, por exemplo, tivessem obtido o prêmio Casa de las Américas e, com exceção de Taberna y otros lugares, de Roque Dalton, que me agradou, eu náo entendia os outros. Sentia-me incapaz de continuar escrevendo poesia, mas a narrativa me interessava enormemente. Lembro que naquela época, só para citar livros cubanos, me impressionou Los años duros, de Jesús Díaz. E, dos autores do boom da mesma época (1967-1968), li La ciudad y los perros, Los cachorros e La región más transparente, que me deixaram totalmente impressionado.

Os diretores da Escola, o casal de argentinos Isabel Herrera e Alberto Panelo, desde o último ano me designaram para trabalhar como assistente de direção de Isabel, e, por essa razão, apesar de graduado em musicalização, comecei, em 1971, a trabalhar como assistente de direção com o grupo de teatro Rita Montaner.

Em 1973 caiu em minhas mãos um número da revista Moncada, que continha uma convocatória para o concurso de literatura policial Aniversario del Triunfo de la Revolución e também um artigo de Armando Cristóbal Pérez, que dizia que era extremamente difícil fazer literatura policial. Na Escola de Arte, tinha deixado de ler romances policiais, que eram considerados por lá como subliteratura. De toda forma, decidi participar e fiz o esboço de No es tiempo de ceremonias. O livro se diferenciava dos romances que eu tinha lido por não ter detetive particular, e sim três policiais que trabalhavam em equipe. Além disso, apareciam os CDR [Comitês de Defesa da Revoluçáo], o que achei simples e lógico, porque a ilha inteira tinha CDR e nenhum detetive particular. Para mim, ter escrito um romance já era um feito suficiente.

Para minha surpresa, No es tiempo de ceremonias ganhou o prêmio, e foi algo sensacional, pois ao ser publicado obteve uma grande repercussão. No ano seguinte ajudei Alberto Molina com Los hombres color de silencio, que ganhou também o prêmio de romance, e em 1976 obtive o prêmio de contos com Para vivir más de una vida. 
Nessa época, o Guiñol Nacional precisava de atores e enviaram vários do Rita Montaner, onde eu trabalhava. Apesar de não ser ator, eu queria ser um deles, e também fui. O sucesso de No es tiempo de ceremonias e meus escassos dotes como ator acabaram me convencendo de que deveria insistir em escrever. E, a partir da experiência no Guiñol, me interessei em escrever teatro infantil. Preparei uma peça, Los apuros de Popito, que obteve uma menção no concurso da Uneac [Uniáo de Escritores e Artistas de Cuba], à qual eu ainda não pertencia. Foi publicada em uma antologia de obras teatrais para crianças (Teatro para niños, seleção, prólogo e notas de Freddy Artiles, Letras Cubanas, 1981), Entrei na Uneac em 1977-1978. Só muito tempo depois desse ingresso soube que minha vida estava ligada ao Quinquênio Cinza, porque a literatura policial era enaltecida, justamente porque pensavam que era uma literatura revolucionária.

E: E no âmbito universitário? Como foi essa época para você??

RPV: Entrei na universidade em 1976, ou seja, depois de já ter publicado. Sei que fizeram expurgos antes do meu ingresso.

E: Ou seja, você não viveu o período mais complicado.

RPV: Exatamente. Entrei no curso para trabalhadores. Imagino que no curso dos mais jovens, que eram mais românticos, devem realmente ter passado a faca... Mas no curso de trabalhadores vínhamos todos de centros laborais, e já se sabia o que se podia e o que não se podia falar. Lá eu nunca vi nenhum tipo de conflito: todos nós estávamos educados na autocensura.

É que o Quinquênio Cinza era parte da vida de qualquer um em Cuba naquele tempo. Você morava em um bairro onde sabia que não podia comentar certas coisas com os vizinhos: depois ia para uma escola em que não podia conversar livremente com seus colegas, e a mesma coisa se repetia quando entrava em um centro de trabalho. Então, quando mais tarde você escrevia um livro e se inseria na vida intelectual, não fazia mais do que acompanhar o mesmo padrão seguido na rua, porém em outra esfera. $O$ Quinquênio Cinza na cultura foi simplesmente um reflexo da censura que permeava toda a sociedade cubana daqueles anos. E se os livros que se escrevem hoje em Cuba são mais abertos e mais críticos, é porque as pessoas também são mais abertas na rua, pelo menos em relação a certos aspectos da sociedade. Em 2003, já estabelecido em Miami, reparei em uma viagem para Cuba que as pessoas criticavam tudo. Em Cuba se diz que "você pode encostar na corrente, mas não no macaco". Quer dizer, pode criticar alguns fatos, dizer que alguma coisa está ruim, mas não mencionar os líderes do país, não pode 
falar de Fidel ou Raúl. Durante o Quinquênio Cinza, não se podia sequer encostar na corrente, nem mesmo chegar perto da corrente.

Vou contar um caso que aconteceu com uma escritora, amiga minha. Quando estava na Escola de Arte, com 17 ou 18 anos, havia uma menina que escrevia uns poemas esplêndidos, e que queria participar do concurso David, para jovens escritores. Mas alguém disse para ela: se você não incluir poemas políticos, não vai ganhar. Faltavam dois dias para o encerramento do concurso e ela pegou o diário do Che, que acabava de ser publicado, e preparou vários poemas vinculados a esse texto. No final recebeu uma menção. Cerca de dois anos depois, ela publicou um livro de poemas totalmente baseado no diário do Che. E quem é que sabia, naquela época, que essa moça escrevia uma belíssima poesia intimista? Ninguém. Ela, em dois dias, não somente mudou esse livro, como sua projeção como futura escritora. Assim eram as regras do jogo do dia a dia de todos os cidadáos. Náo passou pela cabeça dela dizer: mas por que tenho que apresentar poemas políticos? Tomou isso como mais um requisito do concurso, algo que tinha esquecido. Se tivesse enviado o livro tal como estava, não teria ganhado nada. Outras pessoas talvez tenham enviado um livro intimista e náo aconteceu nada.

E: Gostaria de aprofundar um pouco mais o tema do concurso Aniversario del Triunfo de la Revolución do Ministério do Interior (Minint). Nesse sentido, em que medida você acha que as premissas ideológicas tão acentuadas que postulava em suas bases determinaram o posterior desenvolvimento da literatura policial em Cuba? Foi algo fundamental, não?

RPV: Nos anos setenta, as premissas ideológicas desse concurso não eram diferentes das que regiam todas as esferas artísticas e toda a sociedade. Se você vivia em Cuba, sabia o que não colocar em um livro: era o mesmo que você náo podia comentar fora de casa. Quando entrei na Uneac, encontrei nessa instituição um reflexo do que se vivia nas ruas, só que em nível intelectual, temas que não eram abordados e uniformidade nas expressóes sobre a política e a sociedade. Foi depois que se começou a dizer que essa época tinha sido um período da política cultural: o Quinquênio Cinza, mas naquele momento não parecia uma fase, dava a impressão de que sempre tinha sido e sempre seria assim. Depois também fui descobrindo que nos primeiros anos, quando artistas e escritores formados durante o capitalismo, nos anos 50, criaram a Uneac, era permitida uma certa flexibilidade ideológica, que terminou a partir do caso Padilla, e parecia que o que se passou a viver desde então seria a tônica para sempre dominante na Revolução. Também na Uneac, soube mais tarde que se estava prestigiando a literatura policial e que também se estimulava uma poesia combativa, e a poesia intimista deixou de existir. 
Naquela época surgiu também todo tipo de teatro combativo, teatro de pobreza, sem cenografia, estilo Caminando y cantando, que penso que foi a obra que marcou aquela época.

E: Seguindo essa última linha, e passando para o seu trabalho como dramaturgo, você foi um dos raros criadores urbanos que levaram a temática policial ao palco. Para dar um exemplo concreto, penso em Crimen en noche de máscaras, escrita em parceria com Antonio Veloso e que mereceu o prêmio do Aniversario del Triunfo de la Revolución em 1981, na categoria teatro. Esta peça foi estreada pelo Grupo de Teatro Político Bertold Brecht. Como você se lembra da trajetória desse coletivo na cena cubana dos anos setenta e o que você achou da encenação que fizeram de sua obra?

RPV: Nesse ano, o concurso ofereceu, pela primeira vez, o prêmio para uma obra teatral, e decidi escrever uma peça policial que se passasse antes da Revolução. Já havia escrito, com meu grande amigo Antonio Veloso, Las siete puntas de la corona del rey Tragamás, vencedora do prêmio nacional de teatro infantil La Edad de Oro, e entáo empreendemos a tarefa de preparar Crimen en noche de máscaras. Ganhamos o prêmio, e, apesar de trabalhar no Rita Montaner, recorremos ao grupo de Teatro Político Bertolt Brecht, que nos parecia mais capacitado para encenar esse tipo de obra. A peça foi dirigida por Miriam Lezcano, e gostei muito dessa encenação. Inclusive, posso acrescentar que Juan Roca, diretor do grupo de teatro de Miami Habana Fama, que já vivia nos Estados Unidos, viajou a Cuba para ver a peça e disse que se apaixonou pela interação que havia com o público. Foi porque, no meio da investigação na cena, os atores faziam perguntas aos espectadores, e eles respondiam. A diretora não seguiu uma recomendação que tínhamos dado para o final, de que os atores, vestidos de policiais dos anos 40 , retirassem os espectadores do teatro. Parecia-nos que a repercussão seria maior se os espectadores comentassem depois: “ nos expulsaram, não nos deixaram aplaudir, o que é isso?...”. Mas Miriam não quis, fez um final convencional, com os atores se apresentando e o público aplaudindo, mas nossa intenção era que a peça inovasse também nesse sentido.

Sabia que iria falar com você sobre o Quinquênio Cinza e pensei que em $A$ sombra do vento, de Ruiz Safón, se nota como ninguém podia se expressar contra o franquismo naquele momento na Espanha, sob o risco de ser preso. O protagonista do romance, Daniel, um adolescente, cresceu no franquismo $\mathrm{e}$, mesmo que não se diga, se nota que ele sabe o que se pode e o que não se pode dizer. Assim era em Cuba. Não sei como é agora, pois não vou lá desde 2003, e náo vivo lá desde 1995. Mas, nos anos setenta, o Quinquênio Cinza não era só para os intelectuais, e sim para toda a sociedade, que vivia a 
mesma coisa. Fosse você um trabalhador de qualquer setor, de teatro ou um engenheiro, e escrevesse um livro e depois entrasse na Uneac ou no círculo de intelectuais, sem pertencer à Uneac, o que você encontrava não era diferente do que encontrava nas ruas, em seu bairro vigiado pelo CDR. Assim, você escrevia sabendo o que podia colocar ou náo, da mesma forma que o cidadáo comum sabia até onde podia falar. A autocensura funcionava o tempo inteiro, não só no caso dos intelectuais ou jornalistas, mas na sociedade inteira. Não havia (como não há agora) uma editora que não fosse do governo. Durante o franquismo existiam editoras privadas, mesmo que provavelmente viessem a ser reprimidas se publicassem um livro incômodo. Apesar disso, essas editoras existiam. Havia também gráficas particulares, nas quais era possível imprimir um livro clandestinamente. Em Cuba isso não existia e não existe.

O lema da Escola de Arte, que me obrigavam a bradar toda manhã ao içar a bandeira, era: "Antes de artistas, soldados da pátria". Captou a mensagem? Quando comecei a escrever literatura policial foi uma sequência do mesmo tipo de vida, a única que se vivia em Cuba, e que, além do mais, parecia eterna. Naquele momento, se soubessem que você se correspondia com algum parente nos Estados Unidos, você era expulso da universidade. No meu caso, como cidadáo comum, estava imerso nas mesmas limitaçóes de liberdade que todos meus milhóes de compatriotas, e sabia qual comentário de corredor podia impedir de entrar na universidade ou conseguir um bom emprego. $\mathrm{O}$ ambiente que se vivia não era exclusivo dos intelectuais nem das instituiçóes culturais. Era, portanto, uma passagem normal, a do cidadáo cotidianamente reprimido para o escritor reprimido: se você escrevesse algo crítico, a única coisa que conseguiria era que suas palavras não fossem publicadas e que, além disso, você fosse punido. Na verdade, você sequer cogitava isso: sabia, como o jovem que cresceu no franquismo, que há coisas que não podem ser ditas.

E: Agora que você menciona o franquismo, crê que entre os escritores e a censura havia um esquema de "gato e rato" na Cuba daquela época?

RPV: Você se refere a casos como o cinema de Carlos Saura?

E: Mecanismos simbólicos, imagens...

RPV: Quando o Quinquênio Cinza estava no auge, não havia nenhuma liberdade de criação e sequer se permitia o uso da fantasia, razão pela qual não creio que se pudesse usar símbolos para referir-se, tangencialmente, à realidade cubana. Na época que entrei na Uneac, o presidente era Nicolás Guillén, que depois adoeceu, e então o Departamento de Cultura do Comitê Central colocou lá o Armando Cristóbal Pérez, com um cargo chamado "secretário- 
executivo". Na realidade, era ele que dominava a Uneac. À frente da editora Unión, estava Joaquín G. Santana, ou seja: era óbvio, pela trajetória anterior das pessoas nesses cargos-chave, que não se iria permitir lá nenhum tipo de símbolo oculto na criação. Nessa época, inclusive, havia muita discussão sobre a fantasia para os livros infantis, e os escritores de literatura infantil tentavam explicar que a fantasia era necessária para as crianças, porque muitos dirigentes, com poder de decisão sobre o que deveria ou não ser publicado, opinavam que a fantasia era nociva para as crianças de um país socialista. Depois, escritores como Daína Chaviano começaram a publicar contos fantásticos, mas antes não se podia.

Por outro lado, outra coisa que me perguntei quando vinha conversar com você foi de quando a quando vai o Quinquênio Cinza, o que não tenho a menor ideia.

E: Como você sabe, há autores que falam "quinquênio", outros "decênio" e também "trinquênio".

RPV: Também diziam que, depois do término do Quinquênio Cinza, começou o Decênio Prieto, em referência a Abel Prieto como dirigente cultural. Você sabe que existe há esperança de que as coisas mudem. Os intelectuais sempre pressionaram por maior liberdade de expressão. Naquele momento vi como positiva a criação do Ministério da Cultura, com Armando Hart à frente, e posteriormente a nomeação de Abel Prieto como presidente da Uneac. Anteriormente, chegavam convites do exterior para escritores que sabiam que nunca teriam permissão para viajar. E, para um intelectual cubano da ilha, viajar é um evento de magnitude inconcebível, com implicaçôes inimagináveis para um cidadão de qualquer outro país. Mas havia escritores que, apesar de pertencerem à Uneac, não obtinham da Segurança do Estado a autorização para viajar, e isso mudou com Abel Prieto. O fato de ter um Ministério da Cultura também presumia um sentimento de respaldo aos escritores. Além disso, acho que Abel Prieto agiu em defesa de alguns livros difíceis. Por exemplo, os livros de Padura, os primeiros livros dele em Cuba. A ascensão de Abel Prieto como dirigente cultural e a criação do Ministério da Cultura foram os primeiros passos para que o Quinquênio Cinza fosse se tornando um pouco mais suave, mas os momentos mais duros foram muito duros.

E: Mudando de assunto, cito o exemplo de Virgilio Piñera. Ao ser afastado como criador pelos circuitos oficiais de cultura, ele encontrou outras formas de continuar a divulgar sua obra, como as tertúlias, as reunióes literárias realizadas em Villa Manuelita, onde Piñera leu suas peças teatrais ou proferiu conferências. Parece que o apartamento de Abelardo Estorino foi também 
um lugar propício para o encontro de criadores com "problemas". Você viveu essa experiência dos circuitos culturais alternativos?

RPV: Não, não os conheci. Estorino sempre trabalhou no Teatro Estudio. Lá, Raquel Revuelta não permitiu que houvesse problemas com a parametración, como no Rita, onde eu trabalhava. Mas Virgilio Piñera, pelo que entendi, foi colocado em um lugar onde trabalhavam tradutores e nada mais. Era o que permitiam a ele: traduzir. Nada de publicar, nada de encenar suas peças. Eu não o conheci, também nunca trabalhei no Teatro Estudio. Só agora estou sabendo por você que existiam circuitos alternativos de cultura. Pensei que essas pessoas, como Virgilio, tinham sido totalmente relegadas e não podiam fazer nada.

E: Claro, mas me refiro a circuitos alternativos, casas particulares.

RPV: Se existiam, não tinham nenhuma difusão. O que eu quero dizer é que oficialmente não iam permitir, não digo nem uma encenação, mas sequer a leitura de uma obra, daí resultando que o escritor não existisse socialmente. Virgilio deve ter sofrido muito, apesar dessas leituras para uns poucos.

E: Voltando à narrativa policial cubana, queria perguntar como você viu a evoluçáo do gênero desde o começo, considerando que você foi um dos precursores, até o desenvolvimento posterior e o momento atual.

RPV: Há fatores extraliterários que influenciaram o desenvolvimento da narrativa policial da ilha e que nunca vi mencionados pelos acadêmicos que estudam a literatura cubana. Esses fatores são: os direitos autorais e a criação da coleção Radar da editora Letras Cubana. O concurso, com suas limitaçóes ideológicas, tinha pelo menos dois escritores como jurados, e cada prêmio possuía alguma qualidade literária, pelo menos foi o que senti até o fim dos anos setenta. Nessa época, começou-se a pagar direitos autorais, o que foi algo totalmente positivo. $\mathrm{O}$ fator negativo foi que, como os livros policiais eram extremamente populares e pagavam muito, pessoas que nunca tinham escrito um romance ou um conto começaram a escrever policiais porque dava dinheiro. E os editores da Radar, para preencher a nova coleção, começaram a aceitar livros sem nenhuma qualidade, fazendo que o nível baixasse e se começassem a repetir esquemas. Em vez de haver uma evolução do gênero, o que ocorreu foi uma estagnaçáo e uma repetição, o que não quer dizer que náo se produziram obras boas como $Y$ si muero mañana (Luis Rogelio Nogueras, 1978) e Joy (Daniel Chavarría, 1978), que eram interessantes e muito bem escritas. Mas repare que a queda da qualidade não se deu com os 
autores que tinham publicado boas ou razoáveis obras anteriormente, mas com novos autores, que se incorporaram para ganhar dinheiro. Mais tarde, depois de 1989, da queda do bloco socialista e do trauma que significou para os cubanos o julgamento e fuzilamento de Ochoa, Tony de la Guardia e outros dois militares, surgiu Leonardo Padura como escritor policial. Padura foi uma figura-chave porque começou a escrever quando a literatura policial cubana já estava há mais de 15 anos repetindo o mesmo esquema. Mas a mentalidade do povo cubano tinha mudado: havia muita desilusão. Padura foi crítico de literatura policial e então decidiu escrever Passado Perfeito e, pelo que entendi, fui reconstruindo esta história aos pedaços, enviou a obra para o prêmio Aniversario de la Revolución. Creio que Juan Carlos Fernández, que era funcionário do Minint e morreu aqui em Miami, e além disso escreveu Todo es secreto hasta un día e outros livros, era jurado, soube que o prêmio era para Padura e contou para ele confidencialmente. Padura tinha uma viagem, e quando voltou soube que o prêmio não era para ele nem para ninguém: tinha sido declarado vacante, porque alguém ou alguns decidiram que o Minint não poderia premiar esse romance. $\mathrm{O}$ interessante é o seguinte: o autor mexicano Paco Taibo leu o romance e perguntou a Padura se queria publicá-lo em uma editora mexicana que estava começando. De modo que Passado Perfeito foi publicado no México em 1991, 17 anos depois de No es tiempo de ceremonias. Quando li o romance, antes de ser publicado no México, achei que jamais seria publicado em Cuba, por seu conteúdo. Tratava de um dirigente que fizera carreira de revolucionário porque era a única forma de chegar ao poder, ter uma mansão e outras coisas materiais. Isto é, ali se expunha que muita gente se metia a revolucionário por ser a forma de ascender na sociedade cubana. $\mathrm{O}$ personagem realmente era um corrupto, $\mathrm{e}$ tinha tentado roubar milhões de dólares do governo cubano, mas fracassou e acabou se suicidando. Passado Perfeito tem duplo sentido: era um passado totalmente imperfeito. Há outro elemento que temos que levar em conta, o fato de Abel Prieto ser amigo pessoal de Leonardo Padura, e parece que, de alguma forma, por conhecer Padura, Abel Prieto deu seu aval para que o romance fosse publicado. Esse romance representou uma mudança absoluta da literatura policial cubana. Padura publicou depois Ventos de quaresma, que também é violento nas coisas que apresenta, e aquele que me parece o melhor de seus romances com o personagem Conde, que é Máscaras.

Foi a partir disso que surgiram outros escritores policiais em Cuba, como Amir Valle e Lorenzo Lunar, que fazem uma literatura policial que não tem nada a ver com a anterior. Por outro lado, sei que não existe mais a Associaçáo de Literatura Policial da Uneac e o que existe são essas personalidades individuais: não há um grupo coeso como havia antes e não tenho notícias de que ainda exista em Cuba o concurso de literatura policial. 
E: E quanto às coleçóes editoriais, tipo as da Radar e da Capitán San Luiz?

RPV: A Capitán San Luiz era a editora do Minint. Surgiu depois que a literatura policial cubana começou a decair e não publicava nada inovador. Quanto à Radar, não sei o que estará publicando agora, mas sei que publicou romances táo ruins que nunca deveriam ter sido impressos, o que contribuiu para a decadência do gênero. Sei que o Lorenzo Lunar publica em Santa Clara e às vezes em uma editora de Oriente, além de publicar no exterior. Pelo que sei, não publica na Radar.

E: Realmente a literatura policial teve um grande êxito em relação à quantidade de leitores que atraía, certo?

RPV: Em 1986, quando nos reunimos para o Encontro Internacional de Escritores Policiais e fundamos a Associação Internacional, Paco Taibo compareceu a mais de um lançamento que fizemos e disse que, em Cuba, os escritores de literatura policial pareciam atores de cinema, pois multidóes faziam fila para comprar seus livros. Nesse momento já tinham sido publicados vários romances policiais ruins, mas continuava a haver um "boom" e uma excelente comunicação com os leitores. Como você se lembra, publiquei No es tiempo de ceremonias em 1974 e, em 1986, tinham sido publicados muitos romances bons, mas também já havia um declínio nas publicações da Radar. Acontece que estávamos vendo as árvores, e não víamos o bosque. Pensávamos que se publicavam romances bons e ruins, e não percebíamos que o gênero como um todo estava sendo prejudicado.

Tudo isso coincidiu com a queda do bloco socialista. Acabou o papel e aí não se publicou mais nada. Depois, a partir disso, surgiu também uma espécie de permissão, que não havia antes, para que pudéssemos publicar no exterior e para nos relacionarmos com escritores e editores estrangeiros. Lembro que, quando a Associação Internacional de Escritores Policiais foi fundada, nós, os autores de literatura policial, começamos a viajar, e convidamos alguns escritores e editores estrangeiros a visitar Cuba. Gente como o italiano Marco Tropea ou o sueco Arne Blom. Passeamos com eles por Havana, algumas vezes os levávamos para casa porque queriam ver como vivia um cubano, e pessoas que moravam no meu prédio perguntavam se eu não tinha problemas por levar um estrangeiro para casa. Isso agora pode parecer uma loucura para um jovem cubano de 20 anos, porque os estrangeiros estáo em toda parte e o turismo está aberto. Nunca pensei que haveria nenhum problema, porque eram convidados da Uneac, mas essas eram as circunstâncias: convidar um estrangeiro, publicar no exterior por conta própria conta, essas questóes também poderiam ser um pecado. Além do mais, sucedeu que Abel Prieto 
foi a uma reuniáo em que estava o Fidel (eu estava em Cuba nessa ocasiáo), e alguém criticou os intelectuais cubanos que pensavam em viajar para outros países. Abel Prieto disse que era mais honesto que um cubano estivesse trabalhando no México do que desempregado em Cuba. Disse isso na frente do Fidel. Como o Fidel náo disse nada, essa defesa do intelectual cubano foi então sancionada. Na época do Quinquênio Cinza, você podia dizer que queria ir a Jibacoa ou Santiago de Cuba, mas não podia dizer que queria ir a Paris: era um pecado. Depois tudo mudou muito. Penso que os momentos de crise provocam aberturas e, entre elas, surgiu a possibilidade de publicar e trabalhar no exterior.

E: Seu empenho em desenvolver a literatura policial o levou a fundar, junto com Alberto Molina, a revista Enigma (1986-1989) e participar da criação da Associação Internacional de Escritores Policiais (1986). Você poderia, por gentileza, se estender um pouco mais sobre essas duas experiências?

RPV: Bem, essa também foi uma mudança em minha vida. Da mesma forma que o poema que saiu no El Caimán Barbudo e a publicaçáo de No es tiempo de ceremonias, a Associação Internacional, também mudou minha vida, assim como a de Alberto Molina, em especial porque fomos os organizadores do Encontro de Escritores Policiais. Há pouco tempo, a pedido de Lorenzo Lunar, escrevi um artigo sobre a criaçáo da AIEP. Nele expliquei que a subseção de literatura policial da Uneac foi criada em novembro ou dezembro de 1985. Até então, os escritores de literatura policial pertenciam à subseçâo de narrativa, mas nunca nos enviavam aos eventos de narradores, pois nos consideravam autores de um subgênero. A mudança veio do exterior: vinham acadêmicos a Cuba para estudar o fenômeno da literatura policial cubana. Note que, nos anos setenta e oitenta, a narrativa e o cinema, para fugir dos riscos de abordar os temas atuais, se desviaram deles e se ocuparam, em grande escala, da época da escravidão, das lutas de independência e dos anos da República anteriores a 1959. Mas a literatura policial, esta sim, tratava da época atual e, além disso, ao falar de crime, mostrava de forma indireta que não era uma sociedade perfeita. Esses acadêmicos estrangeiros perguntavam pelos escritores policiais e aí surgiu uma boa oportunidade para a criação de uma subseção separada da narrativa, que foi a da literatura policial.

Quando foi aprovada, idealizamos uma revista que eu mesmo pensei que seria pequena, informativa, só para escritores, mas Alberto Molina, um homem repleto de ideias e com muitos relacionamentos, disse que tínhamos que fazer uma revista com difusão mais ampla. Combinou com um amigo de seu bairro, que era subdiretor de Mar y Pesca, uma das mais belas revistas que se faziam em Cuba naquele momento, e o homem disse que podíamos 
imprimir o primeiro número na mesma gráfica, desde que a Uneac pagasse. A Uneac concordou, sob a condição de que fosse uma edição única, exclusiva para o Encontro de Escritores Policiais, e então começamos a prepará-la. Uma amiga minha, Carmen Suárez, doutora em Filologia, pesquisadora literária, com quem estudei na Universidade, me disse: "Coloca número um nessa revista. Você não sabe se vão existir outros números, mas, se você colocar número um, vai constar como uma revista nos anais das publicaçóes cubanas". E foi assim que fizemos.

O Encontro de Escritores Policiais foi um sucesso total, porque ficou muito bom e também por razóes extraliterárias, já que houve um escândalo de corrupção que envolveu muitos artistas plásticos da Uneac. Corrupção do ponto de vista dos dirigentes cubanos: os artistas plásticos estavam desenhando os letreiros dos hotéis em construção, quer dizer, os letreiros dos restaurantes, banheiros etc, e estavam ganhando quantias excessivas, segundo a avaliação do governo. Então, alguém lá de cima disse que estavam enriquecendo. Você sabe que essas coisas são como ondas em Cuba; por exemplo, abrem o mercado no campo e depois fecham, porque dizem que os camponeses estão enriquecendo; pois neste caso aconteceu o mesmo. Foi um escândalo que afetou a Uneac. Ao mesmo tempo, nesse momento, nosso congresso estava em preparação e teve muito êxito. Daí que, após o caso de corrupção que envolveu artistas plásticos, nosso evento foi positivo para a Uneac. Tivemos sorte, pois náo houve nenhum acontecimento nacional ou internacional que interessasse a imprensa, e o nosso congresso esteve todos os dias no noticiário nacional do Granma e do Juventud Rebelde. Enfim, um sucesso total.

Como autores cubanos, tínhamos a ideia de fazer uma espécie de associação de escritores de literatura policial dos países socialistas, pois notávamos que eles tinham os mesmos problemas nossos: eram discriminados nas associaçóes de escritores apesar de escreverem os livros mais vendidos. Então, Paco Taibo propôs criar uma associação internacional ampla, e se comprometeu a convidar autores norte-americanos, já que uma associação de escritores de literatura policial que não incluísse americanos seria risível. Yulian Semionov, por sua parte, se comprometeu a convidar franceses. Daí que aconteceu essa situação extremamente curiosa: a criação em Havana, em um país pequeno como Cuba, de uma associação que existe até hoje, com 10 mil membros em uns 200 países. Os fundadores fomos Alberto Molina e eu, como cubanos; os mexicanos Paco Taibo e Rafael Heredia, que já faleceu; Jiri Prochazka, tchecoslovaco, e o soviético Yulian Semionov, também falecidos, e Daniel Chavarría, uruguaio. A partir daí, começamos a viajar a eventos como a Semana Negra. Isto nos abriu o entendimento em muitos sentidos.

Ao mesmo tempo, a revista Enigma continuou sendo editada, ainda que em condiçôes complicadas, como é de se imaginar quando não se dispóe 
de um local próprio: a gente fazia na minha casa. Apesar disso, chegou a ser, em 1988, a revista mais lida de Cuba, depois de Bohemia, segundo nos disse a distribuidora Ediciones Cubanas. E aconteceu que, como a revista pagava direitos autorais pelos artigos, começaram a se aproximar de mim e de Alberto Molina escritores de literatura não policial, críticos, acadêmicos, para publicar qualquer tipo de artigo sobre literatura policial: éramos os que tínhamos o poder de uma revista e os que viajávamos, razão pela qual nossa imagem mudou completamente para os escritores de literatura não policial e também para nós mesmos. Em primeiro lugar, Alberto Molina e eu nunca tínhamos dirigido nenhuma publicação, daí que fossemos aprendendo na prática. Felizmente essa aprendizagem me serviu para o resto da vida. $\mathrm{O}$ fato de ter sido o codiretor daquela publicação me deu as credenciais para trabalhar na rede de televisão americana CBS e permitiu que o Alberto Molina trabalhasse na distribuidora de filmes Sony, em Madri. Como você percebe, aquela experiência nos marcou.

\section{E: Qual era a periodicidade da revista?}

RPV: Pretendia ser trimestral e conseguimos isso, com exceção de uma ediçáo dupla, de seis meses. Mas, quando acabou o papel, acabou a revista, ou seja, quando caiu o bloco socialista, acabou essa publicação, como muitas outras. Muita gente na rua comentava comigo que lia a revista porque era a única em Cuba que não tinha "teque", como se chama em Cuba o panfleto político. Isto se explica porque as autoridades cubanas gostavam de ter a revista sediada em nosso país, porque pelo menos era uma garantia de que esse órgão, porta-voz de uma associação internacional, não iria falar mal de Cuba ou do socialismo. Mas ao mesmo tempo agradava aos leitores por não conter nada de "teque político". Creio que essa foi uma das causas de seu êxito. Talvez não fosse tão boa, comparada com qualquer revista do exterior, mas em Cuba era um sucesso total.

E: Outra peça publicada com seu nome obteve uma menção no prêmio 13 de Marzo da Universidade de Havana, em 1976. Falo de Leopardos, máscaras y ratones, uma obra que colocava em cena a invasão de Playa Girón. Agradeço se puder contar os meandros da história desse texto, que acho que é mais complicada do que em princípio pode aparecer.

RPV: Essa foi a primeira obra literária que escrevi, além do poema. Foi em 1970: o Quinquênio Cinza estava começando com força total, e um dirigente nacional de teatro achou que os recém-formados de teatro, entre eles meu amigo Hugo Fernández e eu, éramos um exemplo de novos artistas, 
e que, portanto, não deveríamos nos contaminar pelos grupos de teatro já existentes, pelo pessoal de teatro anterior, que, supostamente, tinha sido infectado pelas taras burguesas do passado. Daí foi criado um novo grupo, chamado Cubanacán, composto somente por egressos da ENA. No meu caso, eu não era ator, mas assistente de direção. Nesse momento ninguém pensou na dificuldade de montar peças em que todos seus integrantes tinham 22, 23 ou 24 anos.

Hugo Fernández, um dos graduados, muito inteligente, foi escolhido como o líder do grupo. Entretanto, ocorreu que ele e o resto do grupo começamos a defender certas ideias artísticas que não eram absolutamente contrárias ao governo, mas, naquele momento, esperava-se que fizéssemos realismo socialista. De forma que quiseram destituir o Hugo como diretor e, nesse movimento, dissolver o grupo. Para chegar a isso, disseram que um dia Hugo tinha tocado a nádega de uma menina na ENA. Na verdade, a moça era namorada dele, ele tinha acabado de se formar, era só um ano mais velho do que ela e só estava com a mão na cintura dela, mas foi isso o que inventaram. Dissolveram o grupo. Foi então que entrei no grupo Rita Montaner, mas ele foi posto na rua; não o deixavam trabalhar em nada.

E: De que ano estamos falando?

RPV: Fim de 1970 ou começo de 1971. O grupo começou em 1970. Isso durou pouco. Hugo estava morando na própria ENA, e ao ser expulso ficou sem casa, eu o hospedei na minha: éramos grandes amigos. Naquela ocasião, Hugo me perguntou se eu queria ajudá-lo a escrever uma peça de teatro sobre Playa Girón, que o ajudasse a conseguir a suspensão desse horrível castigo que o impedia de trabalhar em qualquer coisa ligada a cultura ou educação. Concordei: Hugo era meu amigo e uma pessoa tão inteligente que eu achava que aprenderia muito escrevendo com ele. E foi assim: náo sabia como estruturar uma obra e aprendi. E, graças a esse texto, comecei a sentir que podia ser escritor. Enviamos a obra ao prêmio Uneac e não ganhamos nem sequer uma mençáa. Cerca de um ano depois, um dos membros do júri me disse que os jurados tinham sido advertidos de que não podiam premiar aquela obra, porque Hugo, um dos autores, "tinha problemas". Naquele tempo, essa frase, "fulano tem problemas", se referia sempre a problemas ideológicos, e era pior do que ter sido preso por roubar alguma coisa.

Quando soubemos desse problema com a obra, coincidiu que Hugo tinha começado a trabalhar em uma biblioteca, mas, quando um dirigente cultural ficou sabendo, ele também foi despedido de lá. Hugo decidiu ir para Oriente, a regiáo de onde era sua família, para ver se esqueciam dele. Tempo depois me escreveu e disse que assumisse a obra, pois do contrário nunca seria 
publicada. Eu já estava na universidade e já tinha publicado No es tiempo de ceremonias .Apresentei a peça no concurso 13 de Marzo. Ela ganhou uma menção, e decidiram publicá-la. O livro saiu em meu nome, mas acrescentei ao texto uma nota dizendo que considerava Hugo Fernández como coautor. Foi uma obra escrita com o único objetivo de limpar a imagem de Hugo.

E: Isto que você diz me interessa muito. Era muito comum produzir uma obra para limpar a imagem de um autor?

RPV: Penso que, no caso de Hugo, foi uma ideia dele. Não creio que ele tenha ouvido falar de outra pessoa que tivesse feito isso. Depois, fiquei sabendo que era algo habitual. A primeira vez que ouvi falar disso foi por Luis Rogelio Nogueras, o Wichy. Estávamos com nossas respectivas esposas fazendo uma viagem de turismo em Cuba, como prêmio do concurso de literatura policial, ele com seu romance El cuarto círculo, escrito junto Guillermo Rodriguez Rivera, e eu com meu livro de contos Para vivir más de una vida. Wichy entâo comentou comigo que tinha enviado o texto para o concurso para ver se o castigo que lhe haviam imposto já tinha terminado.

E: Nesse sentido, o que acha da aparição, em seu tempo, do livro Acero, de Eduardo Heras León?

RPV: Talvez tenha sido apenas porque Heras León, como excelente escritor, se inspirou por estar conhecendo de dentro o mundo dos operários metalúrgicos, mas entre os escritores correu o rumor de que foi porque tinha sido punido. Depois pensei que esse boato só convinha àquele que estava castigando; era como uma advertência sobre o que poderia acontecer com quem escrevesse o que os dirigentes não queriam.

No caso do meu amigo Hugo, sei que ele teve essa ideia, sem saber que estava acontecendo com outras pessoas. No caso de Wichy Nogueras foi intencional, porque ele me contou que havia escrito para saber se não pesava mais nenhum problema sobre ele. E no caso de Heras, não sei, e especular sobre a razão de ele ter escrito o livro seria subjetivo, mas o rumor que correu não foi subjetivo, o rumor existiu. Li algo escrito pelo próprio Heras sobre uma reuniáo que teve creio que com José Felipe Carneado, que estava, se bem me lembro, à frente do Departamento de Cultura do Comitê Central. Heras perguntou a ele se já náo era suficiente o tempo que estava trabalhando em uma metalúrgica, afastado da cultura, e Carneado respondeu que não só era suficiente, mas que já era além da conta. E foi nesse momento que Heras soube que tinha terminado o seu castigo, porque até então não sabia. Castigavam você, proibiam que publicasse, enviavam você a qualquer trabalho bem duro 
e afastado da cultura, mas, quando se esgotava o tempo, você náo sabia se podia voltar e publicar, porque não ficava claro se o castigo tinha acabado.

E: Em 1995, você chegou a Miami. Quais são as maiores características que identificam a comunidade intelectual da diáspora cubana nessa cidade?

RPV: Em 1995, senti que era extremamente difícil desenvolver um trabalho intelectual aqui. Depois, para minha surpresa, descobri que tem um monte de gente que se reúne, escreve, desempenha atividades literárias, quando pensei que isto era de uma aridez completa. Agora, o que acontece aqui é que não existe nenhuma instituição que nos apoie. Aqui não temos, como em Cuba ou em qualquer país da América Latina, um Ministério da Cultura ou instituiçôes culturais que queiram, por exemplo, homenagear algum de seus escritores. E isso acontece porque Miami não é um país, mas sim uma cidade que fala espanhol dentro de uma nação que fala inglês, e onde não existem só cubanos, mas também venezuelanos, argentinos, enfim, criadores de toda a América Latina. Além do mais, nos Estados Unidos, apesar dos milhóes de pessoas de fala espanhola, não existe sequer um prêmio de romances em espanhol. As editoras que publicam romances em espanhol só editam autores consagrados, não se aventuram com nenhum escritor novo. Portanto, é preciso concorrer no exterior.

Esse é o caminho que percorri. Quando me senti angustiado, escrevi uma espécie de lista de propósitos para ver como posso publicar um livro em algum lugar. É uma espécie de rosário de angústias que chega até agora, que é o melhor momento da minha vida literária em geral.

E: Existe algum ponto de encontro dos escritores na cidade?

RPV: Sim, existe. Por exemplo a livraria Books, de Coral Gables, que além de tudo é um belíssimo lugar. No primeiro domingo de cada mês, Gastón Álvaro, diretor de uma editora de Miami, grande promotor de cultura, organiza atividades culturais em torno da literatura, das quais às vezes participam músicos. É um encontro importantíssimo. Também conheci outros eventos realizados em residências particulares. Pessoalmente, me senti reconfortado, ao saber que existiam esses encontros. De qualquer forma, a possibilidade de publicar no exterior continua sendo extremamente difícil.

E: Falando nisso, como foi sua experiência editorial como autor residindo fora de Cuba? Que recursos você utilizou para continuar publicando? 
RPV: Em relação aos concursos, posso dizer que, quando você procura, mais de $90 \%$ são espanhóis. Você pode achar um concurso no Peru só para peruanos, ou no México para mexicanos, mas a maioria dos concursos literários internacionais são promovidos na Espanha. É terrível: às vezes você fica sabendo que 400 romances participaram do concurso. E como você vai ser melhor do que tantos escritores? Você sabe que haverá muitos romances ruins, mas, entre quatrocentos, tem que haver muitos que sejam bons e pelo menos dez excelentes quanto ao tema e à forma como foi escrito. Além do mais, o júri é sempre espanhol e você terá que interessá-lo por um tema que não lhe é familiar e que não o afeta. Além disso, você tem que considerar que talvez seja verdade algo que li na própria imprensa espanhola sobre a existência de concursos como o de algumas editoras, cujos prêmios já têm nome e sobrenome, que são os dos escritores que tiveram resultados absolutamente rentáveis anteriormente. Ou seja; você tem que descontar muitas coisas. No meu caso, consegui ganhar um concurso com Habana-Madrid, um romance náo policial, um romance de amor com o pano de fundo social da realidade cubana. O protagonista é um economista de uma empresa. Pretendi retratar a vida de um cubano normal, o que pode e o que não pode falar, como tem que lutar para sobreviver economicamente, para alimentar-se, e como tudo isto influi na sua vida amorosa. Há um momento no romance em que, por uma circunstância absolutamente casual, ele é enviado à Espanha para comprar uns tecidos e tem a possibilidade de ficar por lá, junto a uma cubana que se relacionou com ele na juventude e que mora em Barcelona. Além disso, ele deixou um amor em Havana, onde sofreu carência e perdas. Essa tensão, esse conflito, se intensifica até o final da obra. É um romance dividido em quatro partes. As três primeiras se desenrolam em Havana: foram escritas enquanto eu ainda vivia lá. Trouxe essas partes para cá e decidi que não iria acrescentar nelas nada sobre Cuba que eu tivesse aprendido em Miami, graças à informação de que disponho agora. Por exemplo, apesar de estar vivendo em Cuba em 1994, na ocasião do maleconazo, só pude ver as imagens do que aconteceu na minha cidade quando cheguei a Miami. Mas o protagonista também não pode vê-las, razão pela qual tratei de que nada do que soube aqui influenciasse o que o personagem saberia em Cuba. Só o último capítulo, que acontece quando o personagem viaja a Madri, escrevi totalmente com minha experiência posterior de Madri e Miami. É um romance que pessoalmente teve extrema importância para mim e talvez tenha alcançado uma catarse através dele.

Ao mesmo tempo, a editora Random House no México publicou, com o selo Plaza \& Janés, uma coletânea de dez contos policiais meus, intitulada: Un hombre toca a la puerta bajo la lluvia. Cinco desses contos foram premiados na Semana Negra de Gijón, e outros foram premiados anteriormente em 
Cuba. Enquanto literatura policial, se enquadram na categoria neopolicial. São contos muito experimentais, uma busca por inovação dentro do gênero policial.

Enfim, se você tivesse me perguntado sobre minha situação atual como autor antes de setembro de 2009, teria dito que era terrível, mas agora estou vivendo um renascimento de minha carreira literária.

Tradução de Diogo de Hollanda PUC-SP, São Paulo

\section{Referências Bibliográficas}

ARTILES, Freddy (seleção, prólogo e notas). Teatro para niños. La Habana: Letras Cubanas, 1981.

CHAVARRÍA, Daniel. Joy. La Habana: Editorial Arte y Literatura, 1978.

DALTON, Roque. Taberna y otros lugares. La Habana: Casa de las Américas, 1969.

DÍAZ, Jesús. Los años duros. La Habana: Casa de las Américas, 1966.

FERNÁNDEZ, Juan Carlos. Todo es secreto hasta un día. La Habana: Editorial de Ciencias Sociales, 1976.

FUENTES, Carlos. La región más transparente. México: Fondo de Cultura Económica, 1958.

HERAS LEÓN, Eduardo. Acero. La Habana: Editorial Arte y Literatura, 1977.

MOLINA RODRÍGUEZ, Alberto. Los hombres color del silencio. La Habana: Editorial Arte y Literatura, 1976.

NOGUERAS, Luis Rogelio. Y si muero mañana. La Habana: UNEAC, 1978.

NOGUERAS, Luis Rogelio; RODRÍGUEZ RIVERA, Guillermo. El cuarto círculo. La Habana: Editorial Arte y Literatura, 1976.

PADURA FUENTES, Leonardo. Pasado perfecto. Guadalajara: Universidad de Guadalajara, 1991.

PADURA FUENTES, Leonardo. Vientos de cuaresma. La Habana: Unión, 1994.

PADURA FUENTES, Leonardo. Máscaras. La Habana: Unión, 1997.

PÉREZ VALERO, Rodolfo. No es tiempo de ceremonias. La Habana: Editorial Arte y Literatura, 1974. 
PÉREZ VALERO, Rodolfo. Para vivir más de una vida. La Habana: Editorial Arte y Literatura, 1976.

PÉREZ VALERO, Rodolfo. Leopardos, máscaras y ratones. La Habana: Departamento de Cultura, 1976.

PÉREZ VALERO, Rodolfo. Un hombre toca a la puerta, bajo la lluvia. México: Plaza Janés, 2010.

PÉREZ VALERO, Rodolfo. Habana-Madrid. Miami, FL: Plaza Editorial, 2012.

PÉREZ VALERO, Rodolfo. Misterio en el Caribe. Miami, FL: Plaza Editorial, 2015.

PÉREZ VALERO, Rodolfo. Misterio en Venecia. Miami, FL: Plaza Editorial, 2016.

PÉREZ VALERO, Rodolfo. Misterio en Nueva York. Miami, FL: Plaza Editorial, 2017.

PÉREZ VALERO, Rodolfo; VELOSO, Antonio. Las siete puntas de la corona del rey Tragamás. La Habana: Gente Nueva, 1979.

RUIZ ZAFÓN, Carlos. La sombra del viento. Madrid: Planeta, 2001.

VARGAS LLOSA, Mario. La ciudad y los perros. Barcelona: Seix Barral, 1963.

VARGAS LLOSA, Mario. Los cachorros. Barcelona: Lumen, 1967.

VELOSO, Antonio; PÉREZ VALERO, Rodolfo. Crimen en Noche de máscaras. La Habana: Letras Cubanas, 1986.

Emilio J. Gallardo-Saborido. Professor na Faculdade de Educação da Universidade de Sevilha. Doutor pela mesma instituição. Autor das obras: El martillo y el espejo: directrices de la politica cultural cubana (1959-1976) (2009); Gitana tenías que ser: las Andalucias imaginadas por las coproducciones fílmicas iberoamericanas (2010); e Diseccionar los laureles: los premios dramáticos de la Revolución cubana (1959-1976) (2015). Com outros colegas editou Investigaciones sobre la enseñanza del español y su cultura en contextos de inmigración (2014); Presumes que eres la ciencia. Estudios sobre flamenco (2015); Escribir en las disciplinas: intervenciones para desarrollar los géneros académicos y profesionales en la Educación Superior (2017); e Asedios al caimán letrado: literatura y poder en la Revolución cubana (2018). Também publicou artigos, resenhas e entrevistas em periódicos acadêmicos, como o Hispanic Research Journal, Bulletin of Spanish Studies, Hispanófila, Latin American Theater Review, Confluencia e Anuario de Estudios Americanos, entre outros.

E-mail: egallardo2@us.es

Recebido em: 15/01/2018 Aceito em: 15/03/2018 